\title{
REGULATORY AND LIABILITY ISSUES IN HORIZONTAL MULTI-STAgE FraCTURING
}

\author{
KeITH LUfT, ${ }^{*}$ THOMAS O’LEARY,** \\ AND IAN LAING***
}

The last few decades have witnessed greater exploration of oil and gas developments and improvements and evolution in technology that have been driven by the strong demand for oil and gas. Hydralic fracturing techniques have become subject to scrutiny by the media and public in North America and Europe, with attention being paid to the potential or perceived environmental impact associated with such technological developments. This article explains the context and process in which horizontal multi-stage fracturing (HMSF) functions. In addition, the article explores and outlines the legal and regulatory environments in both Canada and the United States, where issues have been raised owing to the wider use of HMSF. The article seeks to provide readers with a better understanding of these emerging and potential legal and regulatory issues.
Au cours des dernières décennies, l'exploration pétrolière et gazière a connu plus de développements, d'améliorations et d'évolutions technologiques motivées par une forte demande de pétrole et de gaz naturel. Les techniques de fracturations hydrauliques sont passées au peigne fin par les médias et le public en Amérique du Nord et en Europe, une attention spéciale étant accordée à l'impact environnemental potentiel et perçu associé avec ces développements technologiques. Cet article explique le contexte et le processus de la fracturation hydraulique horizontale en plusieurs étapes. En outre, l'article explore et cerne les contextes juridiques et réglementaires, au Canada et aux États-Unis, où des questions ont été soulevées relativement au plus grand recours à ce type de fracturation. L'article cherche à aider le lecteur à mieux comprend les problèmes juridiques et réglementaires potentiels émergeant.

\section{TABLE OF CONTENTS}

I. InTRODUCTION . . . . . . . . . . . . . . . . . . . . . . . . . . . . . . . 404

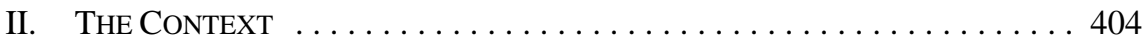

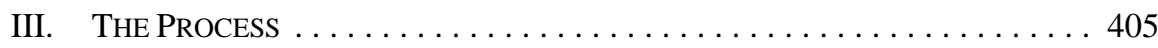

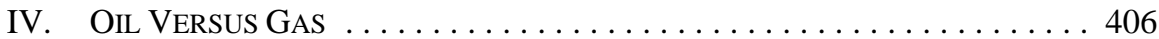

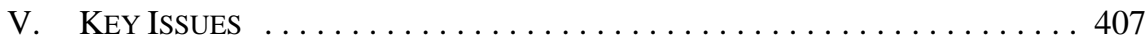

A. Fracture Fluid Disclosure $\ldots \ldots \ldots \ldots \ldots \ldots \ldots \ldots \ldots$

B. WeLl INTEGRITY . . . . . . . . . . . . . . . . . . . . . . 407

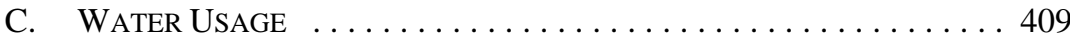

D. WAste DisPosal by InJeCtion . . . . . . . . . . . . . . . . . 409

VI. LEgislative AND REgUlatoRy MANAGEMENT OF

Key IsSUes in SELECTEd JURISDICTIONS . . . . . . . . . . . . . . . . . . . . . . 409

A. Fracturing Fluid Disclosure $\ldots \ldots \ldots \ldots \ldots \ldots \ldots \ldots . \ldots \ldots$

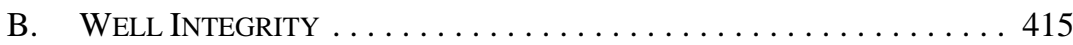

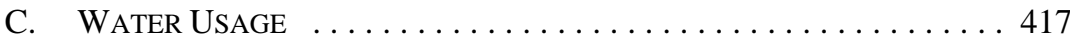

D. WASte DisPosal By InJeCtion $\ldots \ldots \ldots \ldots \ldots \ldots \ldots \ldots \ldots$

VII. FRACTURING-RELATED Litigation $\ldots \ldots \ldots \ldots \ldots \ldots \ldots \ldots \ldots 422$

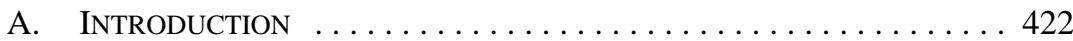

* $\quad$ General Counsel and Senior Vice President, Stakeholder Relations, Penn West Exploration.

*** $\quad$ Partner, Fraser Milner Casgrain LLP.

*** $\quad$ Counsel, Law Department, Imperial Oil Limited. 
B. History of Hydraulic Fracturing Litigation $\ldots . \ldots \ldots . . .422$

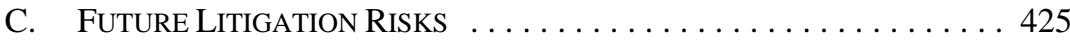

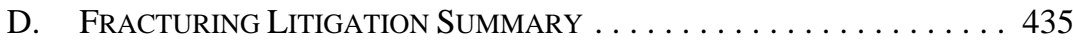

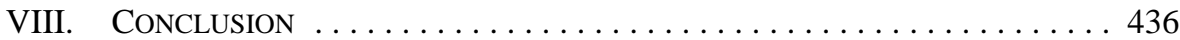

\section{INTRODUCTION}

The history of the oil and gas industry is one strongly influenced by macro-economic forces of supply and demand, and the relative health of the world economy. Over the last few decades, strong demand for oil and gas and the consequent impact on commodity pricing have led to increased levels of oil and gas exploration and development, as well as improvements and evolution in technology. Additionally, the media and public have, at least in North America and Europe, been focused on the potential or perceived environmental impacts associated with oil and gas development generally, and hydraulic fracturing techniques in particular.

Our aim in this article is to educate the reader on what horizontal multi-stage fracturing (HMSF) is, why it exists, and why it matters. We will consider the evolution of legislation and regulations in response to the proliferation of HMSF in some key jurisdictions, and will examine some of the relevant liability and litigation trends. We hope to leave the reader with a basic understanding of the current legal climate and to signal some of the potential trends and developments that may be important in the future.

\section{THE CONTEXT}

The oil and gas industry has a long and proud history of leveraging technology to feed the cyclical supply/demand curve and the ever-increasing world appetite for energy. HMSF is just the most recent example. At its simplest, HMSF is a process by which producers can transform "uneconomic" reservoirs into "economic" ones. Today, one horizontal well with 20 fracturing stages can replace the production that previously required 20 vertical wells and 20 individual fracturing operations, at a fraction of the capital investment.

“Conventional” oil and gas reservoirs generally present interconnected pathways or porosity such that hydrocarbons flow through the formation to a single wellbore with little or no stimulation. "Unconventional" reservoirs are much less porous with poorer connectivity. The rock matrix has smaller grains, leading to less flow, often referred to as "poor quality” or "tight rock." Industry has long been aware of these unconventional reservoirs in tight rock, tight shales, substandard rock at the margins or edges of conventional plays, or source rock formations for conventional reservoirs. HMSF allows the creation of artificial fissures and pathways within unconventional reservoirs, which, when combined with the horizontal wellbore with multiple exposures to the rock face, renders the unconventional conventional.

The key to understanding the practical impacts of this "new" process is to first understand that the underlying technologies are not new. The HMSF process essentially combines two well-established technologies, fracturing and horizontal drilling, with its genesis being the need to feed an undersupplied gas market. 
The practice of fracturing began in the late 1800s, when nitroglycerin was first used to stimulate production from shallow, harder rock in the eastern United States. ${ }^{1}$ The first hydraulic fracturing occurred in 1949 when Stanolind Oil injected 1,000 gallons of napalm thickened gasoline to stimulate a limestone formation at a depth of 800 metres. ${ }^{2}$ The hydraulic fracturing process has become much more sophisticated since 1949, but the basic principles remain the same.

Horizontal drilling technology is the other ingredient. Resource production formations are oriented largely on the horizontal axis. Vertical wellbores can only access the vertical "height" (often only 15 to 90 metres) of the producing formation, whereas horizontal wells are now capable of travelling up to 10,000 metres within the producing formation, often with multiple lateral legs.

Throughout North America, horizontal wells are no longer the exception, they are the norm. Specifically in Canada, the Canadian Association of Petroleum Producers (CAPP) reports that while the number of wells drilled has dropped roughly 30 percent from 20,000 in 2008 to 14,000 in 2011, the actual number of metres drilled has dramatically increased from 22.6 million metres drilled in 2008 to 30.7 million metres drilled in $2011 .^{3}$ This demonstrates the prevalence of horizontal drilling.

\section{THE PROCESS}

A hydraulic fracturing operation generally involves four steps:

(1) Injecting fluids into the formation to pressurize the rock;

(2) Initiating and increasing fractures or fissures in the reservoir rock to create pathways from the wellbore into the formation to allow hydrocarbons to flow;

(3) Pumping sand or other proppant into the newly created fissures to prop open these pathways or channels; and

(4) Recovering back the fracturing fluid to the surface and allowing the hydrocarbons to flow through the wellbore.

The process begins by drilling a vertical wellbore section down to the depth of the target formation and then turning horizontally to run anywhere from 500 to as much as 10,000 metres within the prospective formation. In this stage, a number of horizontal laterals may be kicked off from the vertical segment. Once the well is drilled and cased, holes or perforations are made in the production casing to control and provide entry points for the fracturing to occur. The size, number, and spacing of the individual fracture points are primarily reservoir dependent. The assessment and appraisal phases of reservoir development

Carl T Montgomery \& Michael B Smith,“Hydraulic Fracturing: History of an Enduring Technology” (2010) 62:12 Journal of Petroleum Technology 26 at 27.

Ibid.

CAPP, “Wells and Metres Drilled in Canada, 1981-2011," online: CAPP < http://membernet.capp.ca/ $\mathrm{SHB} /$ Sheet.asp?SectionID=1\&SheetID=147>. 
help operators determine what the optimal number and magnitude of fracturing events will be, balanced by an analysis of the capital required to complete the well.

Wells are then completed by pumping down large volumes of pressurized water-based fluid containing a small amount of proppant and chemical substances into the horizontal wellbore. This fluid is forced out into the formation at controlled intervals or stages to create tiny pathways or fractures in the rock within which the sand proppant stays lodged when the fracture fluid returns up the wellbore. These newly created pathways allow natural gas or oil to flow where it previously could not. The fracturing process increases access to hydrocarbons in the formation by artificially "stimulating” or improving reservoir porosity.

Intensive surface operations are required to effect HMSF completions. Large numbers of trucks are required for hauling sand and pumping units are required, as well as data collection units and surface tanks or reservoirs, to hold the water as it is assembled for the fracture and then recovered to be treated, reused, or injected into a disposal well. Whereas the drilling process has historically been the single largest capital requirement in upstream operations, HMSF completion operations often require two or three times the amount of capital required to drill and case the well.

\section{OIL VERSUS GAS}

The HMSF "technological revolution" began in the middle of the last decade with widespread HMSF usage in the Barnett, Haynesville, and Bossier gas shales of the US. It allowed substantial and economical gas production from these shales. HMSF use has become prevalent in the unconventional gas reservoirs in the Marcellus shales in the eastern US, the Utica shales in Canada, the Western Canadian Sedimentary Basin, and internationally, including areas of France and Poland. As a result of HMSF, gas production and proven reserves increased sharply. Today, HMSF is ubiquitous. For example, companies operating in the Western Canadian Sedimentary Basin are drilling as many as 90 percent of their wells based on HMSF. ${ }^{4}$

It has not stopped with gas. The Pembina Cardium pool is the largest conventional oil reservoir in Canada and one of the largest in North America. Decades ago, the Alberta Energy Resources Conservation Board (ERCB) quantified this pool as having eight billion barrels of oil originally in place. ${ }^{5}$ Over the last several years, recovery factors have dramatically increased, with the ERCB recognizing a 7 percent increase in initial established reserves for the Pembina Cardium pool. This increase is largely a result of extensive horizontal drilling. ${ }^{6}$

With the advent of HMSF, not only have reserves increased, but the areal limits of pools have been expanded by allowing economic production from lower permeability rock. In Western Canada, oil reservoirs being targeted today are largely light oil plays trapped in

See e.g. PennWest Exploration, PennWest Drilling Program - 2011/2012 (2012) [unpublished, archived at PennWest Exploration].

ERCB, ST98-2011 - Alberta's Energy Reserves 2010 and Supply/Demand Outlook 2011-2020 (Calgary: ERCB, 2011) at 4.1.2.

Ibid at 4.1.3. 
source rocks or tight formations, previously uneconomic to produce. The ERCB currently estimates that the number of HMSF oil wells drilled in Alberta will almost double, increasing from 745 in 2010 to 1200 from 2011 to 2013. ${ }^{7}$

The advent of HMSF technology in Canada, the US, and indeed around the world is truly game changing, with the potential to satisfy world energy demands for decades to come. One need look no further than the price of natural gas in North America (lower than once seemed imaginable) to appreciate the dramatic impact that this technology has had in a very short time frame on the North American gas supply/demand balance.

\section{KEY ISSUES}

\section{A. Fracture Fluid Disclosure}

Fracture fluid selection is primarily driven by reservoir properties including rock characteristics, rock chemistry, and pressures. Water and sand generally compose roughly 99 percent of injected fracture fluid with the balance being chemicals geared towards improving the viscosity and lowering the friction of the water as it transports the sand into the fissures created in the formation. The most common fracture fluid ingredient by an order of magnitude is water. However, other liquids as well as gases such as carbon dioxide, propane, and nitrogen can also be used.

A sensitive issue surrounding the HMSF process involves chemicals used in HMSF operations. The primary concern raised by stakeholders centers around the nature of chemical treatments being injected into reservoirs to facilitate the fracturing process. The potential for these often toxic or hazardous chemicals to contaminate groundwater or surface water is often expressed. In response, as discussed below, legislators and regulators have begun to look at ways to ensure that these chemicals can be tracked and monitored in the public interest by requiring regulatory and even public disclosure of their nature and use.

\section{B. WELL INTEGRITY}

Perhaps the most significant practical factor impacting HMSF risks is that of well integrity. Even prior to the advent of HMSF technology, North American legislatures in hydrocarbon-producing jurisdictions had taken steps to regulate well construction and monitoring to ensure well integrity was established and maintained. ${ }^{8}$ Risks to groundwater and surface resources, as well as risks of unsafe and economically harmful events, were sought to be minimized. 
Operations are required to be conducted such that groundwater is isolated from the wellbore, and water sources are protected from completion and production operations. ${ }^{9}$ Conductor pipe may be installed and cemented around the wellbore to create a barrier to stop water, mud, or chemicals from seeping into porous dirt, clay, gravel, and sands near the surface. The well is then drilled to (and in many cases, well past) the legislatively determined base of groundwater and a second steel casing (surface casing) is cemented in place within the wellbore. The cement is required to set prior to continuing drilling, and bond logs are run to determine that the well has good integrity between the rock face and the surface casing. Depending on the completion technology and the expected reservoir characteristics, intermediate casing may also be used. Finally, the well is drilled to its total depth (or length). In some cases a second or third casing may also be inserted to facilitate production from the reservoir, post stimulation. ${ }^{10}$

A second set of considerations involve the integrity of nearby producing, suspended, or abandoned wellbores. These may be monitored to determine if there is any weakness in their integrity and to determine whether pressure fluctuations are experienced while completion operations are being carried out in nearby new horizontal wellbores. Many jurisdictions are currently reviewing and refining their approach to notification, testing, and monitoring in the vicinity of HMSF operations.

Another issue linked to well integrity involves what is commonly referred to as a "frack-over." This is essentially the propagation of fractures beyond the targeted or intended formation and subsequent flow of hydrocarbon and fracturing fluids into adjoining formations. Although there is no scientific evidence demonstrating the occurrence of frackovers, the concept receives tremendous attention in the media and has caught the eye of regulators. The United States Environmental Protection Agency (EPA) recently released a draft report which considers potential frack-overs in discussing the potential link between reported water contamination in Pavillion, Wyoming and fracturing chemicals from nearby gas wells. ${ }^{11} \mathrm{~A}$ final report is pending. That report will certainly be the subject of much public debate, discussion, and further study.

While there may be opportunities for a fracture to communicate with other existing wells drilled into or through the same formation, to date the authors are not aware of any documented communication with water sources via fractures across hundreds of meters of intervening formation, or even any scientific evidence that this is possible. Industry suggests that hydraulic pressure forces fracturing fluids into the ground such that they cannot physically travel back up into the water supplies and that intervening layers in the Earth's crust create a watertight barrier that prevents chemicals from moving towards the surface.

9 Ibid.

10 For a typical well schematic, see American Petroleum Institute (API), Hydraulic Fracturing Operations - Well Construction and Integrity Guidelines, API Guidance Document HF1, 1st ed, (Washington, DC: API, 2009) at 5.

11 Dominic C DiGiulio et al, Investigation of Ground Water Contamination near Pavillion, Wyoming (Draft) (Ada, OK: EPA, 2011), online: EPA < http://www.epa.gov/region8/superfund/wy/pavillion/EPA ReportOnPavillion_Dec-8-2011.pdf $>$. 


\section{WATER USAGE}

An HMSF operation may use millions of gallons of water. It is not surprising that public scrutiny of fresh water usage in HMSF operations continues to grow across North America as the number and size of HMSF operations grows. Legislatures, regulators, and industry continue to focus on ways to minimize the HMSF water "footprint.” Some of the different legislative and regulatory schemes in place regarding water use in HMSF operations are considered later in the article.

\section{WASTE Disposal BY INJECTION}

As discussed earlier, the final phase in the completion operation is one in which fracturing fluids are recovered from the formation. Significant volumes of recovered fracturing fluid, flowback, and produced water often require management. These fluids may then be treated and recycled, sent for external disposal, or re-injected into defined and approved formations via injection wells. Public perception and safety concerns have raised the profile of this issue. The regulatory regimes concerning deep well injection of these substances are described later in this article.

\section{LEgISLATIVE AND REgULATORY MANAGEMENT OF KEY ISSUES IN SELECTED JURISDICTIONS}

The advent of HMSF throughout North America has not only resulted in an abundance of natural gas production, but it has been met with significant controversy over safety and environmental impacts. The EPA and many American states have responded to this growing concern with new laws and policies. Some Canadian provinces have also enacted or pledged to enact similar laws and policies to deal with the perceived risks surrounding HMSF operations. In New York, Quebec, and some other jurisdictions, fracturing operations have been halted altogether pending further assessment of the extent of the short and long term environmental impacts, with New York having now proposed extensive regulations on the subject. $^{12}$

This part seeks to provide a very general overview of how British Columbia, Alberta, and seven selected US jurisdictions manage the four key HMSF issues summarized above. Aside from British Columbia and Alberta, the regulatory approaches taken in Texas, Wyoming, Oklahoma, Colorado, Pennsylvania, and by the EPA have been considered, as have the extensive New York Proposed Regulations. These jurisdictions are all invested in HMSF issues. The states considered all have significant or potential HMSF activity and the EPA exercises jurisdiction in respect of waste water management. Many of these jurisdictions have, since mid-2010, either expressed an intention to, or have already enacted fracturingrelated legislation. In addition to the overview of various regulatory approaches being taken, recommendations on appropriate regulatory management from key government and industry associations will also be considered.

12 NY, Department of Environmental Conservation, "High Volume Hydraulic Fracturing Proposed Regulations,” online: Department of Environmental Conservation <http://www.dec.ny.gov/regulations/ 77353.html> [New York Proposed Regulations]. 
The commentary below seeks to describe in general terms the relevant regulatory approaches in place and, where appropriate, to draw some high level conclusions on potential regulatory trends. In that respect, it is postulated that recent regulatory changes, as well as those being proposed going forward, are generally based on the elevation of best practices, the importing of those best practices as operational requirements, and the establishment of transparency in operations and regulatory management.

\section{A. Fracturing FLUID Disclosure}

\section{PUBLIC Disclosure}

A number of general trends respecting fracturing fluid disclosure are evident in the selected jurisdictions. One is the trend toward greater and more direct public disclosure. Until 2010, there was minimal public access to this type of information and no specific public disclosure requirements in the jurisdictions reviewed. Detailed information on chemicals used in fracturing operations was not generally reported to regulators.

In September 2010, Wyoming became the first US state to require regulatory disclosure of fracturing chemicals. ${ }^{13}$ Numerous other states have followed suit and some have gone further to require the disclosure of chemicals used in fracturing operations to be specified in publicly accessible online registries.

The relevant disclosure registry in the US is a website operated by the United States Ground Water Protection Council and the Interstate Oil and Gas Compact Commission. ${ }^{14}$ It is intended as a public clearinghouse of hydraulic fracturing information on a well by well basis and became operational on 11 April 2011. Of the states reviewed, Texas ${ }^{15}$ and Colorado ${ }^{16}$ have recently enacted very similar legislation requiring the disclosure of fracture fluid ingredients and volumes on the FracFocus website. The New York Proposed Regulations expressly require public disclosure of fluid ingredients and volumes as well, but the means of disclosure is not specified. ${ }^{17}$

Several other states do not directly mandate public disclosure, but require operators to maintain detailed records of fluid components which must either be disclosed to, or can be compelled by, the regulator. For example, Wyoming requires detailed regulatory disclosure of fluid components and volumes. ${ }^{18}$ Public access is determined on the basis of a general statute ensuring access to public records, subject to certain exceptions. ${ }^{19}$ The Pennsylvania rules in effect since February 2011 require similarly detailed regulatory disclosure, which must be made publicly available at the regional offices of the regulator. ${ }^{20}$

Wyoming Oil and Gas Conservation Commission, Rules and Regulations, ch 3 § 45 [Wyoming Rules]. Online: FracFocus <http://fracfocus.org>.

Tex Admin Code tit $16 \S 3.29$ [Texas Rules].

2 Code Colo Regs 404-1 § 205A [Colorado Rules].

Supra note 12, § 560.3(c).

Wyoming Rules, supra note 13 , § 45(d).

Ibid, § 45(f); see Wyoming Public Records Act, Wyo Stat Ann §16-4-203(d)(v) for such an example. Pa Code tit 25 § 78.122(a) [Pennsylvania Rules]. 
Oklahoma also uses a "regulatory reporting" model, ${ }^{21}$ but only requires reporting of the "Fluid/Prop amounts" used. ${ }^{22}$ Oklahoma has no apparent requirement for any public disclosure of fracturing fluid components, though records of the public regulator and public officials are generally accessible by the public under general access to information legislation, subject to specified exceptions. ${ }^{23}$

In Canada, British Columbia (working with CAPP) has recently established a requirement of online public disclosure similar to the FracFocus system in the US. ${ }^{24}$ New regulations require operator disclosure of fracture fluid components, including chemical types and volumes. ${ }^{25}$ The relevant British Columbia Oil and Gas Commission (BCOGC) website ${ }^{26}$ is extremely similar in all respects to the FracFocus website developed in the US.

Alberta requires a degree of regulatory disclosure of fracturing fluids, but does not currently mandate the public disclosure of any information related to fracturing operations. ${ }^{27}$ Presumably, public access to these records would be governed by general legislation concerning access to information held by government entities.

The trend toward public disclosure has been strongly reinforced by industry associations and governments. In Alberta, the ERCB has recently stated its intention to introduce a detailed public disclosure requirement for fracturing fluid content. ${ }^{28}$ The leading industry group in Canada, CAPP, has recently released its own voluntary standards and guidelines for its members that call for companies to provide full and public disclosure of fracture fluid constituents on publically accessible company or third party websites. ${ }^{29}$

Similarly, public disclosure of fracturing fluid composition has been recently recommended by the United States Department of Energy, Secretary of Energy Advisory Board, Shale Gas Production Subcommittee (SEAB). ${ }^{30}$ This subcommittee was formed to assist the public, industry, and regulators in "identifying measures that can be taken to reduce the environmental impact and improve the safety of shale gas production." 31 The SEAB was formed on order of President Obama, ${ }^{32}$ and its recommendations should prove highly influential.

Okla Admin Code § 165:10-3-25 [Oklahoma Rules].

Ibid; Oklahoma Corporation Commission, “Completion Report: Form 1002A” (revised 2009) [Form 1002A].

Open Records Act, Okla Stat tit 51 § 24A.1 (2000).

British Columbia Ministry of Energy and Mines, Information Bulletin 2012ENER0001-000010,

“Canada’s First Hydraulic Fracturing Registry Now Online” (9 January 2010), online: Government of British Columbia <http://www2.nes.gov.bc.ca/news_releases_2009-2013/2012ENER0001-000010. pdf $>$.

Drilling and Production Regulation, supra note 8, s 37.

Online: FracFocus <http://fracfocus.ca>.

See Well Drilling and Completion Data Filing Requirements, ERCB Directive 059 (27 September 2011) [ERCB Directive 059].

Rebecca Penty, "Alberta to make frack fluid disclosure mandatory this year,” Calgary Herald (22 February 2012), online: Calgary Herald < http://www.calgaryherald.com/business/Alberta+make+frack +fluid+disclosure+mandatory+this+year/6194314/story.html>.

See CAPP, Guiding Principles for Hydraulic Fracturing (September 2011), online: CAPP <http://www. capp.ca/getdoc.aspx?DocId=195096\&DT=NTV > [CAPP, Guiding Principles].

See US Department of Energy, "Secretary of Energy Advisory Board — Shale Gas Production Subcommittee 90-Day Report” (18 August 2011) at 3, online: US Department of Energy <http:// www.shale gas.energy.gov/resources/081811_90_day_report_final.pdf > [SEAB Report].

Ibid at 1 .

Ibid at 5 . 


\section{Detailed Disclosure}

A second general trend is that the required disclosure is becoming more rigorous and detailed. Though some jurisdictions (including Alberta and Oklahoma) require disclosure of only generic information on fracturing fluid ingredients, other jurisdictions reviewed require more detailed reporting. Details that may be required to be disclosed to the regulator or directly to the public include the chemical manufacturer, as well as the concentration, volume, and other specific information on the chemical additive ingredients.

In this respect, Oklahoma has the least rigorous disclosure regime of the jurisdictions considered. Only "Fluid/Prop amounts" must be reported. ${ }^{33}$ It does not appear that any other disclosure of fracturing fluid ingredients is mandated by law in Oklahoma. However, the opportunity for the regulator to require more extensive disclosure appears to exist. There is a general prohibition against water pollution by “deleterious substances" 34 and the regulator has access to all well records and has the power to compel more detailed recording and reporting of fracturing information. ${ }^{35}$ A January 2011 state review of hydraulic fracturing in Oklahoma recommended regulatory disclosure of hydraulic fracturing fluid ingredients. ${ }^{36}$

Wyoming requires disclosure of the base fluid source, the type of chemical additive (for example, proppant and corrosion inhibitor), each chemical compound name, each Chemical Abstracts Service (CAS) number for chemicals within the additive, and the rate of concentration for each additive. ${ }^{37}$ The volume or concentration of each chemical within the additive is not required to be disclosed, though the regulator has discretion to request such formulary disclosure. ${ }^{38}$

The New York Proposed Regulations are similar to the Wyoming regulations in this respect, requiring Material Safety Data Sheets (MSDS) ${ }^{39}$ for each additive product that is subject to the MSDS requirements (for hazardous chemicals) of the Occupational Safety and Health Administration (OSHA). ${ }^{40}$ The New York Proposed Regulations require disclosure of amounts and concentrations of additive products and disclosure of the chemical ingredients within, but like Wyoming, do not appear to require disclosure of amounts and concentrations of the chemical ingredients within the additives.

Pennsylvania seems to go a step further and requires disclosure of the amounts and concentrations of chemicals within the additives. Specifically, Pennsylvania requires additional disclosure of the percent by volume of each chemical listed in each MSDS for an additive product. ${ }^{41}$ Similarly, Texas requires disclosure of each additive ingredient subject

\footnotetext{
33 See Form 1002A, supra note 22.

34 Oklahoma Rules, supra note 21, § 165:10-3-10(a).

Ibid, §§ 165:10-1-6(f), (g).

State Review of Oil \& Natural Gas Environmental Regulations (STRONGER), Oklahoma Hydraulic Fracturing State Review (Oklahoma City: STRONGER, 2011), online: Natural Gas Subcommittee of the SEAB <http://shalegas.energy.gov/resources/071311_stronger_oklahoma_hfreview.pdf>. Wyoming Rules, supra note 13, § 45(d).

Ibid.

New York Proposed Regulations, supra note 12, § 560.3(c)(1).

See US Department of Labor, "Material Safety Data Sheet," online: OSHA < http://www.osha.gov/dsg/ hazcom/msds-osha174/msdsform.html>.

Pennsylvania Rules, supra note 20, § 78.122(b)(6)(ii).
} 
to the MSDS requirements of OSHA, as well as the CAS number for each such chemical ingredient and the actual or maximum concentration of each such chemical ingredient. ${ }^{42}$ Other (non-MSDS) chemicals added to the fracture fluid must also be disclosed, along with CAS numbers, though volumes and concentrations of those chemicals need not be reported. ${ }^{43}$ The effect seems to be that in both Texas and Pennsylvania, a degree of formulary disclosure is mandated but only in respect of substances subject to the MSDS rules of the Federal OSHA statute.

Colorado is the high water mark in this respect, requiring disclosure of amounts and concentrations, not only of chemical substances subject to the MSDS rules in OSHA, but also of any other chemical intentionally added to the base fluid. Specifically, the Colorado regulation requires disclosure of "the maximum concentration, in percent by mass, of each chemical intentionally added to the base fluid." 44 By virtue of this provision, Colorado requires a somewhat higher level of disclosure than Texas and Pennsylvania.

Recently enacted British Columbia regulations seem to require a level of disclosure similar to that required in Colorado. ${ }^{45}$ As of 1 January 2012, a Hydraulic Fracturing Fluid Report is required to be posted by operators on the Canadian FracFocus website. The report must identify all fluid ingredients as well as CAS numbers for each and the concentration of each chemical, whether such chemical is subject to regulation as hazardous, and whether used in an additive product or otherwise added to the fracture fluid. ${ }^{46}$ This provision should import an equivalent level of disclosure to that required in Colorado.

Alberta's required disclosure is currently much less detailed than that required in British Columbia and Colorado. Only generic information on fracture fluid ingredients must be disclosed to the regulator in Alberta. Specifically, the required Well Reports must disclose the propping agents, the carrier fluid (type of fluid, volume of each type, whether energized, source), and additives (generic name, supplier, and purpose).$^{47}$ The recent ERCB pledge to require public disclosure of fracturing chemicals ${ }^{48}$ is suggestive that more detailed disclosure requirements are on the way. This would be consistent with the trend as already established in British Columbia, Texas, Colorado, and under the New York Proposed Regulations.

\section{TRADE SECRETS}

Producers and operators are understandably vigilant in guarding competitive information, and as the level of required chemical disclosure increases, protection of this information becomes more important. To address these concerns, legislatures in all jurisdictions where fracturing specific regulations or guidelines contemplate public disclosure of fracture fluid ingredients have enacted explicit trade secret disclosure protections for information that is deemed to be sensitive, proprietary, or confidential.

Texas Rules, supra note 15, §§ 3.29(c)(1)-(2).

Ibid, §§ 3.29(c)(1)(A), 3.29(c)(2)(A)(xi).

Colorado Rules, supra note 16, § 205A(b)(2)(A)(xi).

Drilling and Production Regulation, supra note 8.

Ibid, s 37; BCOG, Well Completion, Maintenance and Abandonment Guideline (Victoria: BCOGC, 2012), s 6.4 .

ERCB Directive 059, supra note 27 at Appendix 3.

See Penty, supra note 28. 
Regulations governing hydraulic fracturing in Texas, ${ }^{49}$ Colorado, ${ }^{50}$ Wyoming, ${ }^{51}$ Pennsylvania, ${ }^{52}$ and the New York Proposed Regulations ${ }^{53}$ explicitly provide exemptions for public disclosure of trade secrets, though the exact features of the enactments vary. Wyoming and Pennsylvania allow for claims of confidentiality with the efficacy of claims of trade secrets being determined in accordance with general access to information legislation. ${ }^{54}$

Trade secret protection is not absolute. Texas regulations on fracturing exempt information from trade secret protections where the information is required by health professionals and emergency responders. ${ }^{55}$ Colorado regulations contain similar exemptions to trade secret protections and add to these an exemption when such information is required by the regulator in responding to a spill or complaint. ${ }^{56}$

A unique feature of the Texas regulation restricts challenges of this trade secret determination to a narrow group of parties. ${ }^{57}$ Only the landowner, adjacent landowners, and government agencies with appropriate jurisdiction can challenge. No other jurisdiction seems to impose this type of limitation, though general laws and principles of standing would presumably apply to trade secret challenges, and limit to some degree who could challenge trade secret determinations.

The new British Columbia regulations are generally in line with those in Texas and Colorado in terms of trade secret protections. Confidential information is protected with the determination of confidentiality made under the federal Hazardous Material Information Review Act. ${ }^{58}$ Where information is protected on this basis, a party may withhold the CAS number, and under some circumstances, the concentration of one or all of the ingredients to be disclosed. ${ }^{59}$

Alberta has no apparent fracturing specific legislation or guidelines related to withholding of confidential information regarding fracturing fluid. This is not surprising, given that only generic information regarding fracture fluid is currently reported. It can be expected that the pending changes to the regime in Alberta, which will apparently require detailed public disclosure of fracturing fluid ingredients, will also address trade secret protection.

Texas Rules, supra note 15, § 3.29 .

Colorado Rules, supra note 16, § 205A.

Wyoming Rules, supra note 13, § 45(f).

Pennsylvania Rules, supra note 20, § 78.122(c).

Supra note 12, § 560.3(c)(2) and Part 616.

Wyoming Rules, supra note 13; Pennsylvania Rules, supra note 20, § 78.122(c); Right-to-Know Law, 65 PS $\S \S 67.101-67.3103$ (Act 3 of 2008).

Texas Rules, supra note $15, \S 3.29(\mathrm{~g})$.

Colorado Rules, supra note 16, §§ 205A(b)(5), 205A(d)(2).

Texas Rules, supra note 15, §3.29(2)(f).

RSC, 1985, c 24 (3rd Supp).

BCOGC, Fracture Fluid Report Upload Manual (Victoria: BCOGC, 2012) at 11-12. 


\section{TIMING OF Disclosure}

Another common feature of regulation in this area is to require the disclosure of fluid components only after the fracturing operation is completed. A 30-day reporting period after completion is usual, ${ }^{60}$ although not universal. Colorado allows operators 60 days to report after completion of fracturing operations. ${ }^{61}$ All jurisdictions reviewed required some degree of post-operation reporting regarding fracturing fluid use.

Pre-operation disclosure may be an emerging trend. Wyoming is currently the only jurisdiction reviewed that requires fluid composition disclosures to be made at the permit stage. The New York Proposed Regulations, however, would mandate significant preoperational disclosure in these respects as well. ${ }^{62}$ The Wyoming regulation appears to require disclosure of the same information at the permitting stage (on a "proposed" basis) ${ }^{63}$ as is required on an actual basis following post well stimulation operations. ${ }^{64}$ There is apparently no express prohibition in Wyoming against the actual fluid components used being different than those set out in the pre-operation disclosures.

The New York Proposed Regulations are of particular interest in this respect. Detailed preoperational disclosure of fracture fluid ingredients is required. A permit applicant must also provide documentation that proposed chemical additives in the fracturing fluid exhibit reduced "aquatic toxicity" and "pose a lower potential risk to water resources" and to the environment than available, effective, and feasible alternatives. ${ }^{65}$ These requirements are unique among the jurisdictions reviewed. The New York Proposed Regulations further state that products other than those identified in the well permit application may not be used without specific approval from the regulator. ${ }^{66}$ This could be extremely inconvenient for operators who may wish to alter fracturing fluid ingredients in the field in response to new information obtained during operations.

\section{B. WELL INTEGRITY}

Given the volume and nature of fluid used in HMSF operations, maintaining well integrity is considered critical. Well integrity rules seek to accomplish the following two basic objectives:

1 To isolate the internal conduit of the well from the surface and subsurface environment. This is critical in protecting the environment, including the groundwater, and in enabling well drilling and production. 
Though there appears to be no common regulatory template for ensuring well integrity in the jurisdictions reviewed, it is clear that well integrity issues have been the subject of a high degree of prescription and continue to receive significant attention from regulators in all those jurisdictions. Given the concerns with surface and subsurface contamination in the context of HMSF, and particularly water quality concerns, well integrity regulation should continue to attract close scrutiny.

A detailed consideration or comparison of the drilling and well construction requirements and standards mandated in the various jurisdictions is beyond the scope of this article and the expertise of the authors. The commentary on the subject below has, therefore, been kept general in nature and is confined to basic regulatory features and broad trends.

A number of general conclusions can be drawn about the current regulatory treatment of well integrity issues. First, regulatory requirements to ensure well integrity are generally not, with a few minor exceptions relating to monitoring and reporting, specific to hydraulically fractured wells. They tend to be of general application, many having been in existence for decades.

In addition, all jurisdictions reviewed expressly embrace the principles of insulating groundwater as well as other reservoirs and formations. While specific measures vary, they each seek to establish minimum standards for casing, cementing, ongoing well testing and monitoring, and for regulatory reporting on these subjects.

Notably, the level of detail in the regulatory standards and requirements regarding well drilling, construction, and integrity monitoring varies widely. Requirements are expressed primarily in a general and purposive manner in some jurisdictions (such as British Columbia $^{68}$ and Pennsylvania ${ }^{69}$ ), whereas other jurisdictions (Alberta ${ }^{70}$ and Colorado, ${ }^{71}$ most particularly) have chosen to spell out operational requirements and standards in significant detail. For example, the relevant British Columbia regulations ${ }^{72}$ and Well Drilling Guideline ${ }^{73}$ only provide that casings be designed to withstand maximum load and service conditions that can be reasonably anticipated and address the depth and cementing of surface casing. Further details are left for the regulator to assess upon submission of a detailed proposed casing and cementing program. ${ }^{74}$ Alberta has taken the opposite approach and set out very detailed and extensive casing and cementing standards that prescribe acceptable materials and detailed integrity testing, as well as performance and monitoring procedures and requirements. ${ }^{75}$

Regulations concerning well casing requirements among the jurisdictions reviewed tend to have broad similarities. It does not appear that conductor casing is universally required in any of the jurisdictions reviewed. Only Alberta seems to specifically set out the circumstances when conductor casing is "required for well control," providing in those

Drilling and Production Regulation, supra note 8, ss 2, 16-19.

Pennsylvania Rules, supra note 20, § 78.73(c).

ERCB Directive 009, supra note 8; ERCB Directive 010, supra note 8.

Colorado Rules, supra note 16 , § 317.

Drilling and Production Regulation, supra note 8, s 18.

BCOGC, Well Drilling Guideline, supra note 8 at s 3.2 .

See BCOGC, Well Permit Application Manual, revised August 2012 (Victoria: BCOGC, 2012) at 31.

ERCB Directive 009, supra note 8; ERCB Directive 010, supra note 8. 
instances that it be set between 20 and 30 metres into a competent (stable) zone and cemented to surface. ${ }^{76}$ Surface casing must, in all jurisdictions, be extended a specified depth below the deepest known useable or fresh groundwater (25 metres or 50 feet below are examples) and be fully cemented in place from the bottom of the casing to the surface. Intermediate casing may or may not be used, but is generally not required by regulation except in defined circumstances. Regulations do not generally direct that it be cemented to surface. The New York Proposed Regulations are exceptions in these respects, requiring both intermediate casing on all fractured wells and that such intermediate casing be cemented to surface. $^{77}$

The jurisdictions reviewed all impose some standards or protocols for testing and monitoring the integrity of each well, both before the commencement of fracturing operations and after. This includes the monitoring of nearby wells (oil, gas, and/or water) to ensure their integrity, and as a further check on the integrity of the fractured well.

A unique feature in British Columbia and Alberta is the imposition of special rules for shallow operations. In Alberta, shallow wells are defined as being less than 200 metres deep, ${ }^{78}$ and in British Columbia as being less than 600 metres deep. ${ }^{79}$ Both provinces require the use of non-toxic drilling fluids for these shallow wells and impose heightened construction, integrity testing, and monitoring requirements for such wells. ${ }^{80}$

The clear trend appears to be toward increased strictness and detail in well integrityrelated regulations and standards. The New York Proposed Regulations and recent changes in Alberta ${ }^{81}$ and British Columbia ${ }^{82}$ are indicative of these attempts to elevate and mandate best practices. The recently published CAPP guidelines, which contain a moderate level of detail and recommended minimum well construction requirements, reinforce the trend. ${ }^{83}$ In the US, the SEAB has urged further "quantitative measures” to achieve best practices in, inter alia, well design, construction, and integrity monitoring. ${ }^{84}$ This suggests a SEAB preference for further detailed rule making on these subjects. The American Petroleum Institute has also recently published detailed well integrity standards as a response to concerns about the safety and environmental impacts of HMSF specifically and hydraulic fracturing generally. ${ }^{85}$

\section{WATER USAGE}

Hydraulic fracturing often requires the use of significant amounts of water, particularly when targeting gas reservoirs. That water must come largely from surface or groundwater

ERCB Directive 009, ibid, s 3.1; ERCB Directive 008, supra note 8 at 19.

New York Proposed Regulations, supra note 12, §§ 560.6(c)(13)-(14).

Shallow Fracturing Operations - Restricted Operations, ERCB Directive 027 (14 August 2009) [ERCB Directive 027].

BCOGC, Well Drilling Guideline, supra note 8, s 3.2; BCOGC, Well Completion, Maintenance and Abandonment Guideline, supra note 46, s 3.2.1; ERCB Directive 027, ibid.

ERCB Directive 027, ibid.

ERCB Directive 008, supra note 8; ERCB Directive 010, supra note 8.

BCOGC, Well Drilling Guideline, supra note 8.

CAPP, Guiding Principles, supra note 29.

SEAB Report, supra note 30.

API, supra note 10. 
sources. Regulatory jurisdiction over water sourcing and usage generally rests with individual states in the US and with the Canadian provinces. The general regulatory approaches and current trends are considered below.

In all jurisdictions, separate permits are mandated for the withdrawal of groundwater and surface water. There are, in some cases, exceptions to the permitting requirements for low volume users, ${ }^{86}$ but these are not generally material for HMSF operations. Generally, an applicant must apply for a licence to use water in fracturing operations through a specific government department. Colorado has a unique alternative process whereby applicants can instead proceed through a "Water Court" system in order to obtain water use rights. Seven water divisions exist in the state, each with a Water Court possessing both legal and engineering expertise to adjudicate water use requests. ${ }^{87}$

Applicants under the permitting regimes reviewed must generally disclose the volume and source of water to be withdrawn. The only exception noted relates to British Columbia's groundwater withdrawals, which are not subject to a volume-based licencing regime, ${ }^{88}$ though this situation may soon be addressed through law reform. ${ }^{89}$ The disclosure of water volumes at this stage is generally of maximum amounts to be withdrawn and, in some cases, specific information as to whether the amount withdrawn will exceed a given threshold must be disclosed. In Texas, for example, applicants must advise whether withdrawals will exceed ten acre-feet per year for surface water. ${ }^{90}$ The duration of intended use is also to be specified. Permits are then granted based on the duration and volume of anticipated usage.

The degree to which an applicant must provide operational detail and justification for water withdrawals varies. Pennsylvania's requirements for fracturing-related withdrawals in the Marcellus shales are uniquely rigorous in these respects. A detailed Water Management Plan must be submitted at the permitting stage, which specifies 30 day maximum average daily quantities, maximum withdrawals, a Withdrawal Impacts Analysis for each source of water, and various other information. ${ }^{91}$ Though not as demanding of information, the Alberta regime requires applicants to provide a written rationale for the amount of water an operator

See Water Act, RSBC 1996, с 483, s 42.

Colorado State Judicial Branch, "Water Courts," online: Colorado State Judicial Branch <http:// www.courts.state.co.us/Courts/Water/Index.cfm>.

The Water Act, supra note 86, s 1.1 limits regulatory controls over groundwater as follows:

(1) Subject to a regulation under subsection (2), Part 2 [Licensing, Diversion and Use of Water and

Related Matters] and Part 3 [Water Users' Communities] of this Act do not apply to ground water.

(2) The Lieutenant Governor in Council may, by regulation, fix a day on and from which some or all of Parts 2 and 3 of this Act apply to ground water in British Columbia or in an area of

British Columbia the Lieutenant Governor in Council designates in the regulation.

A report of stakeholder submissions in 2009 and 2010 can be found in “Living Water Smart: BC's Water Plan,” online: Living Water Smart <www.livingwatersmart.ca>. About 900 stakeholder written submissions were received and are summarized in British Columbia's Water Act Modernization Report on Engagement (Victoria: Ministry of Environment, 2010), online: Living Water Smart <http:// www. livingwatersmart.ca/water-act/docs/wam_report_on-engagement.pdf>.

Railroad Commission of Texas, "Water Use in Association with Oil and Gas Activities Regulated by the Railroad Commission of Texas," s 3, online: Railroad Commission of Texas <http://www.rrc.state. tx.us/barnettshale/wateruse.php>.

Pennsylvania Department of Environmental Protection, “Form 550-PM-0G0087 (4/2009): Water Management Plan For Marcellus Shale Gas Well Development Example Format,” online: Pennsylvania Department of Environment Protection <http://www.elibrary.dep.state.pa.us/dsweb/Get/Document74083/5500-PM-OG0087\%20Application\%20Example.doc $>$. 
plans to withdraw on an annual basis. ${ }^{92}$ Similarly, in Wyoming ${ }^{93}$ and Oklahoma, ${ }^{94}$ the applicant is required to demonstrate that the water will be put towards a "beneficial use."

Permits in all jurisdictions are dependent on the type of use (mining, industrial, domestic, etc.). Among the jurisdictions examined, only Pennsylvania (for Marcellus shale development) and the New York Proposed Regulations require specific water use permits for hydraulic fracturing. The other jurisdictions lump fracturing in with mining and other industrial uses for permitting purposes.

Requirements for metering and reporting of water withdrawal and use in fracturing operations are not universal, but are becoming more common. The New York Proposed Regulations would require operators to meter water usage, to maintain this information, and to provide it to the regulator upon request. ${ }^{95}$ Pennsylvania, through its Water Management Plans, also requires continuous metering and disclosure of water use. ${ }^{96}$ In British Columbia, the regulator now imposes quarterly reporting, record-keeping, and auditing rules for all short-term (maximum of one year) surface water approvals under section 8 of the Water Act. ${ }^{97}$ As noted, there is not currently a similar British Columbia requirement for volume monitoring of groundwater withdrawals. In Alberta, the requirement to report actual water use is reserved for large volume users. ${ }^{98}$

The regulatory trend appears to be toward more rigorous monitoring and disclosure of water use. Pennsylvania's Water Management Plan requirements, enacted in 2009, and the New York Proposed Regulations that would significantly increase the rigour of regulatory oversight of water use, are indicative of this trend. The 2011 changes to the British Columbia surface water use an approval scheme, ${ }^{99}$ imposing quarterly reporting requirements and broadening the scope of the water sources subject to regulatory oversight, are also consistent with this trend.

Other trends may be emerging as well. One such potential trend is toward direct public disclosure of water use. As of April 2012, direct public disclosure is not required by regulation in any of the jurisdictions reviewed. However, in late 2011, the SEAB urged public disclosure of the flow and composition of water usage throughout the fracturing and clean up process. ${ }^{100}$ The Guiding Principles for Hydraulic Fracturing, published by CAPP

Government of Alberta, Environment and Sustainable Resource Development, "Water Allocation," online: Alberta Environment <http://environment.alberta.ca/03134.html>.

State of Wyoming, "Form UW 5: Application for Permit to Appropriate Ground Water," online: Wyoming State Engineer's Office <http://seo.state.wy.us/PDF/UW5_0909.pdf>.

Oklahoma Water Resources Board (OWRB), “Application for a Permit to Use Groundwater,” online: OWRB <http://www.owrb.ok.gov/supply/watuse/pdf_wat/app_gw.pdf>; OWRB “Application for a Permit to Use Surface or Stream Water," online: OWRB <http://www.owrb.ok.gov/supply/watuse/ pdf_wat/app_sw.pdf>.

New York Proposed Regulations, supra note 12 at $\S \S 750.1,750.3 .13$. The New York regulator, according to the Proposed Regulations, will maintain a monitoring and reporting requirement. Well operators must meter the water used at each well for each event, record the amounts, maintain records of each truck/pipeline delivery of water and the source of the water, and furnish the records to the regulator upon request.

Pennsylvania Rules, supra note 20.

Changes in Section 8 Short Term Water Use Approvals, BCOGC Directive 2011-02 (2 March 2011) at s 4, online: BCOGC <http://www.bcogc.ca/document.aspx?documentID=1063\&type=.pdf > .

Government of Alberta, supra note 92.

See Water Act, supra note 86.

US Department of Energy, supra note 30 at 2. 
in late 2011, include the principle of safeguarding the quality and quantity of groundwater resources and a commitment to measure and publicly disclose water use. ${ }^{101}$ These endorsements could influence future water management initiatives.

\section{WASTE DISPOSAL BY INJECTION}

In the HMSF process, wells are stimulated by pumping millions of gallons of fracturing fluid into rock formations at high pressure to fracture the rock. As the injection pressure is reduced, much of the fluid returns to the surface, leaving sand or other proppant behind to prop open the fractures and allow gas or oil to flow within the reservoir and up the well. A portion of the fluid remains underground ${ }^{102}$ and may return to the surface (along with substances naturally occurring in the formation) as flowback or produced water. Fluid recovered at the surface may be recycled, but considerable volumes may remain and require disposal. The operator must somehow dispose of this fluid without risking surface or groundwater contamination.

A number of options for disposal exist, including transportation to offsite disposal, evaporation, and discharge into waterways. Due to expense, environmental risk, or both, deep well disposal of this fluid waste is often preferred. This section will, therefore, focus on the various regulatory approaches to deep well injection.

A defining feature of the regulatory framework applicable to hydraulic fracturing in the US is that the EPA exercises jurisdiction under the Safe Drinking Water Act ${ }^{103}$ over "waste water," including fluid that has been used in fracturing operations as well as flowback and produced water. Under that legislation ${ }^{104}$ and the EPA's associated rules, ${ }^{105}$ the EPA has established the Underground Injection Control (UIC) program setting out regulations for injection and disposal wells. Wells for the injection of fluids associated with oil and gas production are classified as Class II wells under that program and subject to specific requirements under the UIC program. ${ }^{106}$ States may assume "primary enforcement responsibility" of these requirements by establishing underground injection control requirements that meet or exceed the EPA standards - a process referred to as establishing "primacy.", ${ }^{107}$ The EPA approach has, therefore, set the US template, with relatively minor divergence.

There is a mixed track record on primacy. Of the states considered, Oklahoma, Wyoming, and Texas have established total primacy over all injection and disposal wells, and Colorado has established primacy for Class II injection wells. ${ }^{108}$ New York and Pennsylvania are

Supra note 29 at 1.

This varies of course, and operators try to maximize fluid recovery: Venture Engineering \& Construction, "Marcellus Shale Play - Water Treatment Options Worth Considering" (17 September 2006), online: Venture Engineering <http://www.ventureengr.com/2008/09/marcelus-shale-play-watertreatment-options-worth-considering/>.

42 USC § 300f (1996).

Ibid, §§ 300h-300h-8.

40 CFR § 144-147 [EPA Rules].

Ibid, § $144.6(\mathrm{~b})$.

EPA, “Water: Underground Injection Control — UIC Program Primacy,” online: EPA < http://water.epa. gov/type/groundwater/uic/primary.cfm>.

EPA, “Class II Wells - Oil and Gas Related Injection Wells (Class II), online: EPA <http://water. epa.gov/type/groundwater/uic/class2/index.cfm>. 
governed completely by the EPA. The regulatory controls, restrictions, and requirements established by Oklahoma, Wyoming, Texas, and Colorado are broadly similar to those of the EPA, so will not be commented on specifically.

The EPA and applicable state UIC programs establish basic requirements for Class II wells that includes provisions concerning:

(1) Prohibition of underground injection without authorization;

(2) Construction requirements, including casing and cementing to ensure well integrity;

(3) Geological separation from underground sources of drinking water;

(4) Mechanical integrity tests at regular specified intervals;

(5) Annual reporting of injection fluids;

(6) Reporting of the physical and chemical characteristics and geological data of the strata to be used for injection;

(7) Operating parameters for maximum injection pressures and amounts;

(8) Studies and monitoring of nearby water and other wells;

(9) Notifications to area residents and businesses; and

(10) Plugging and containment requirements. ${ }^{109}$

The ERCB regulates injection and disposal wells in Alberta. It has outlined disposal well requirements in Directive $051 .{ }^{110}$ Directive 051 includes the ERCB's requirements for waste reporting, ${ }^{111}$ logging, ${ }^{112}$ monitoring programs, ${ }^{113}$ initial pressure tests, ${ }^{114}$ formation stability testing, ${ }^{115}$ and operating parameters. ${ }^{116}$ These requirements are generally similar in nature to those in the EPA's UIC program. Specific requirements vary, including those governing frequency of reporting, maximums for initial pressure tests, and logging requirements.

In British Columbia, the BCOGC regulates injection and disposal wells under the Drilling and Production Regulation. ${ }^{117}$ Applications for disposal wells are made to the BCOGC to ensure that oil and gas resources are not impacted, the proposed disposal or injection zone is compatible with produced water, produced water will remain within the underground

EPA Rules, supra note 105, §§ 144, 146.

Injection and Disposal Wells - Well Classifications, Completions, Logging, and Testing Requirements, ERCB Directive 051 (March 1994).

Ibid, s 2.5 .

Ibid, s 5.0

Ibid, s 7.2.

Ibid, s 7.1

Ibid, Appendix 3.

Ibid, s 8.0.

Supra note 8. 
formation, and the applicant has obtained the necessary rights to the formation. ${ }^{118}$ The BCOGC also requires a Monthly Injection/Disposal Statement form to be submitted, reporting volume of fluid and average wellhead pressure. ${ }^{119}$ Casing and cementing requirements, logging requirements, and pressure tests for well integrity requirements exist and are similar to those in Alberta. Indeed, the BCOGC specifically refers applicants to Alberta's Directive 051 for logging guidelines. ${ }^{120}$

In summary, the nature of the injection and disposal well requirements in Alberta and British Columbia are comparable to those of the EPA and the US jurisdictions examined that have established UIC primacy. There would not appear to be any specific regulatory trends with respect to deep well disposal, though the ever increasing scrutiny of HMSF could provide impetus toward stricter requirements for monitoring and reporting deep well disposal information in the future. The EPA is currently in the course of examining the relationship between fracturing and drinking water contamination, which may yield conclusions relevant in this area. A final report is expected in 2014. To the extent that any changes to the current deep well disposal regimes are pursued in the near future, it should be expected that these will seek to elevate and mandate best practices and to increase operational transparency.

\section{FRACTURING-RELATED LITIGATION}

\section{A. INTRODUCTION}

As oil and gas producers in the Western Canada Sedimentary Basin increasingly rely upon HMSF to access petroleum and natural gas reserves in low porosity/low permeability formations, environmental groups, NGOs, and private landowners have voiced concerns about possible adverse environmental impacts. Concerns include water quality, noise and traffic, air quality, and, in some areas, links have been drawn between hydraulic fracturing and seismic activity. There has been a tremendous amount of media coverage regarding the prevalence of HMSF technology and the environmental impacts that may arise therefrom. It is not surprising, therefore, that within that context of both increased intensity of operations and public scrutiny, litigation is one of many risks facing oil and gas producers that make use of HMSF techniques.

\section{B. History OF HydRAULIC FRACTURING Litigation}

\section{United STATES LitigATiON}

Over the past decade, the expansive growth in shale gas and tight oil development in the US has resulted in high levels of drilling activity. In many cases, this occurs on freehold lands in urban areas without a long history of oil and gas development, and in states which

BCOGC, "Oil and Gas Commission Fact Sheet" (September 2011), online: BCOGC <http://www. bcogc.ca/documents/publications/Fact\%20Sheets/Hydraulic_Fracturing_and_Disposal_of_ Fluids_Final.pdf $>$. document.aspx?documentID=901\&type=.pdf $>$. 
may not have highly developed regulatory regimes. Those factors, among others, have resulted in a much more active litigation landscape than currently exists in Canada.

At present, there are approximately 20 active lawsuits brought by private landowners in the US that include allegations of contamination of soil, water, or air, and in some cases, personal injury, arising from or related to hydraulic fracturing operations. ${ }^{121}$ These lawsuits have been commenced in various states, including some with long histories of oil and gas development (for example, Texas, Colorado, and Louisiana), and some where the high level of such activity is more recent (for example, Arkansas, Pennsylvania, New York, and West Virginia).

In generic terms, these lawsuits can be characterized as simple tort actions brought by private landowners seeking damages for property damage, and in some cases personal injury, as a result of hydraulic fracturing operations. A review of these outstanding tort actions is instructive for oil and gas producers in Canada, and their legal counsel, as most include similar allegations of fact and rely upon common causes of action.

The causes of action alleged in these lawsuits typically include nuisance, trespass, negligence, negligence per se, strict liability/ultra-hazardous activities, and, where freehold lands are involved, breach of contract. The relief sought in these various lawsuits typically include claims for compensatory/remediation damages, damages for diminution of property value/stigma claims, damages for personal injury including the cost of future medical monitoring, injunctive relief, and punitive damages. Despite the volume of lawsuits commenced in the US over the last several years, none has yet proceeded to judgment and it is therefore unknown at this point whether any of the plaintiffs will ultimately be successful in proving the allegations made and recovering damages as a result.

The various lawsuits brought by private landowners in the US serve as a useful guide for Canadian producers, since facts similar to those alleged in those cases could arise in Canada and there are similar causes of actions available to Canadian plaintiffs.

In addition to the environmental contamination-based lawsuits commenced in the US, liability and legal responsibility as between competing oil and gas producers as a result of hydraulic fracturing operations is similarly more developed. In particular, the law related to subsurface trespass and the "rule of capture" has received extensive consideration from both the courts and academic commentators. ${ }^{122}$ While many of the US cases on these issues were determined with specific reference to the applicable regulatory and statutory regimes of the jurisdiction where they were decided, they remain instructive in considering how similar

See e.g. Maring v Nalbone, No K12009001499 (NY Sup Ct 2009); Zimmerman v Atlas America, LLC, No 2009-7564 (Pa Ct Com Pl 2009); Fiorentino v Cabot Oil \& Gas Corp, 750 F Supp 2d 506 (MD Pa 2009); Scoma v Chesapeake Energy Corp, No 3:10-cv-01385 (ND Tex 2010); Hagy v Equitable Production Co, No 2:10-cv-01372 (SD W Va 2010); Mitchell v Encana Oil \& Gas (USA), No 3:10-cv02555 (ND Tex 2010); Ginardi v Frontier Gas Services LLC, No 4-11-cv-00420-BRW (ED Ark 2012).

See e.g. Colleen E Lamarre, “Owning the Center of the Earth: Hydraulic Fracturing and Subsurface Trespass in the Marcellus Shale Region” (2011) 21:2 Cornell JL \& Pub Pol’y 457; Owen L Anderson, “Subsurface ‘Trespass': A Man’s Subsurface Is Not His Castle” (2010) 49:2 Washburn LJ 247; Bruce M Kramer \& Owen L Anderson, "The Rule of Capture — An Oil and Gas Perspective” (2005) 35:4 Envtl L 899. 
issues might be resolved by Canadian courts. These issues will be considered in the western Canadian context in greater detail below.

\section{CANADIAN LITIGATION}

Despite the recently heightened level of scrutiny in Canada from landowners, environmental groups, and regulators, there has been only one lawsuit commenced by a private landowner that seeks relief for environmental damage arising from hydraulic fracturing operations. ${ }^{123}$ The Ernst lawsuit alleges that the plaintiff's water supply was contaminated as a result of hydraulic fracturing operations carried out as part of Encana's coal bed methane drilling activities near her home in the Rosebud area of Alberta. ${ }^{124}$ The facts, causes of action relied upon, and damages alleged in the Ernst lawsuit compare closely with many of the similar lawsuits that have been commenced in the United States.

Specifically, Ms. Ernst has alleged that she has suffered general and aggravated damages, which include:

(a) substantial reduction in the value of the Plaintiff's property due to the initial and continuing contamination of the property's water supply and the corresponding loss of use of the property's water well;

(b) loss of use of the property and loss of amenity associated with the property including that caused by the initial and continuing contamination of the property's water supply;

(c) environmental damage to property that the Plaintiff, owing to her strongly held environmental beliefs, particularly values for its natural environmental qualities; and

(d) mental and emotional distress and worry caused by living in a house that is at risk of exploding, and caused by the knowledge that the Plaintiff, her family and her friends had, unbeknownst to them, consumed water containing unknown contaminants with unknown potential health effects. ${ }^{125}$

As against Encana, Ernst has quantified her claim for general damages in the amount of $\$ 500,000$. She also seeks special damages in the amount of $\$ 100,000$, aggravated damages in the amount of $\$ 100,000$, restitutionary damages in the amount of $\$ 1$ million, and punitive and exemplary damages in the amount of $\$ 10$ million. ${ }^{126}$

Causes of action alleged by Ernst in her claim against Encana include negligence, nuisance, strict liability, ${ }^{127}$ and trespass. The Ernst lawsuit is in its very early stages. At the time of writing, Statements of Defence have not yet been filed. While the case remains in its infancy, it indicates to Canadian producers the types of environmental contamination claims brought by private landowners that they might face as a result of hydraulic fracturing operations.

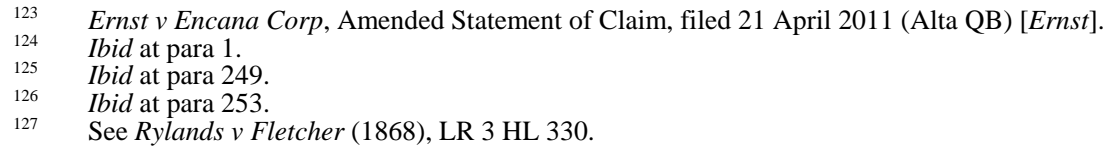


There is also a dearth of Canadian litigation with respect to claims brought by oil and gas producers seeking damages arising from hydraulic fracturing operations conducted by other producers. There are no reported decisions with respect to such claims and the authors are aware of only one active lawsuit where such allegations are made. ${ }^{128}$ In CrossAlta, commenced in 2009, the plaintiffs own and operate a gas storage reservoir. The Statement of Claim alleges that in 2001 a natural gas well that had been abandoned in the Basal Quartz zone in 1980 was fracture stimulated and put back on production. It is further alleged that the fracture stimulation breached the barrier between the storage reservoir and the zone from which the well was producing, resulting in the unlawful production of storage gas by the defendants. $^{129}$

Causes of action relied upon by CrossAlta include conversion, unlawful interference with economic interests, and unjust enrichment. The relief sought includes claims for an interim and permanent injunction directing the defendants to shut-in and abandon the producing well and prohibiting them from drilling any further wells into the Basal Quartz pool, damages in the sum of $\$ 40$ million for production of storage gas, and punitive damages of $\$ 500,000$. $^{130}$

On 11 January 2011, the plaintiffs successfully obtained an interim injunction directing that the defendants' well be shut-in pending determination of issues at trial. ${ }^{131}$ While the defendants have acknowledged that their well is in communication with the storage reservoir, ${ }^{132}$ they deny that the communication was caused by the fracture stimulation, alleging instead that the gas storage reservoir was not properly defined and that any communication is naturally occurring. ${ }^{133}$ The CrossAlta action remains active and the issues unresolved.

\section{FUTURE LitigATION RISKS}

The provinces in western Canada have highly-developed regulatory regimes that impose strict requirements on oil and gas producers that are designed to ensure that all operations are conducted safely, without environmental impacts to landowners or adverse impacts on other producers. The scarcity of Canadian litigation arising from hydraulic fracturing operations, despite the fact that many thousands of such operations have been conducted, is a reflection of the efficacy of those regulatory regimes and of the sound operational practices employed by oil and gas producers in western Canada. Nevertheless, in the event that producers fail to adhere to regulatory requirements, or otherwise fail to conduct their operations in accordance with good oilfield practice, damage to private landowners or other producers could result and lead to litigation. In addition to those circumstances of operational failure, the consequences of increased drilling and technological advances in both the length of horizontal wells and

CrossAlta Gas Storage \& Services Ltd v Bonavista Energy Trust (11 January 2011), Calgary 090115314 (Alta QB) [CrossAlta].

CrossAlta Gas Storage \& Services Ltd v Bonavista Energy Trust, Statement of Claim, Action No 090115314 (Calgary Registry) in the Court of Queen's Bench of Alberta, filed on 13 October 2009 at paras 9, 16-17.

Ibid at para 30

CrossAlta, supra note 128 at para 25.

CrossAlta Gas Storage \& Services Ltd v Bonavista Energy Trust, Statement of Defence of Nexen Inc, ExxonMobil Canada Ltd and ExxonMobil Canada Energy, Action No 0910-15314 (Calgary Registry) in the Court of Queen's Bench of Alberta, filed on 28 July 2010 at para 9.

Ibid at paras 8-9. 
the number and size of fracturing stages per well may lead to legitimate conflicts of competing interests, and thus further risk litigation, arising as between producers.

In the following part, consideration is given to a number of circumstances that may give rise to litigation and the risks that oil and gas producers may face, from both private landowners and other producers.

\section{LITIGATION RISKS VIS-À-VIS PRIVATE LANDOWNERS}

It would be a fruitless exercise to attempt to detail all of the circumstances in which operational failures might result in damage to private landowners. Discharges of fracking fluid or waste water at the surface, or poorly constructed or designed well bores, resulting in contamination of soil and ground water or emissions effecting air quality are obvious scenarios.

\section{a. Causes of Action}

The causes of action that would typically be relied upon in such actions include trespass, nuisance, strict liability, negligence, and possibly breach of contract if the operative lease contains covenants with respect to maintaining the condition of the land. ${ }^{134}$ In addition to those causes of action, many of the existing US lawsuits arising from hydraulic fracturing operations plead a form of strict liability based upon ultra-hazardous activities. This doctrine has been recognized in some US jurisdictions and has been recognized as a possibility in Canadian legal literature:

Occasionally, language appears in a Rylands v. Fletcher decision that furnishes a glimpse of a new basis of strict liability, free of the historic restraints of non-natural use, escape and mischief. This emerging theory can be termed strict liability for abnormally dangerous activities. Pursuant to this principle, there are a limited number of activities so fraught with abnormal risk for the community that the negligence standard is felt to provide insufficient protection against them. Consequently, these extra-hazardous activities should be governed by a stricter form of liability that insists on compensation for all the losses they generate, even when they are conducted with reasonable care.

In other words, there are two general types of activities which are regulated by two different theories of tort liability. Firstly, there are ordinary pursuits that create normal risks, which are controlled by negligence law. Secondly, there are other "types of conduct which, although they cannot be styled wrongful, are either so fraught with danger, or so unusual in a given community, that it is felt that the risk of loss should be shifted

In addition to the common law causes of action referred to herein, Part 4 of British Columbia's Environmental Management Act, SBC 2003, c 53 creates a broad statutory cause of action for recovery of the costs of remediation of contaminated sites. For a detailed summary of the scope and application of that legislation, see Krista Prockiw \& Allyson Baker, The Low Down and Dirty: Statutory Liability for Contaminated Site Cleanup In British Columbia (Vancouver: Clark Wilson LLP, 2010), online: Clark Wilson LLP <http://www.cwilson.com/publications/environmental/low-down-and-dirty.pdf>. 
from the person injured to the person who, merely engaging in such conduct, created the risk which resulted in harm.”135

This new theory, if accepted in Canadian law, would go beyond the strict liability imposed by the rule in Rylands v. Fletcher. There would be no requirement for an "escape" of a dangerous substance, nor would the defendant's use of his or her property need to be classified as "special” or "non-natural." Strict liability would be imposed for any damages caused, based entirely upon the ultra-hazardous nature of the defendant's conduct. ${ }^{136}$

Despite favourable academic commentary, this doctrine of strict liability has not yet gained acceptance in Canadian law, and recently was rejected expressly. Inco was a class action lawsuit in Ontario that arose from the operation of a nickel refinery. As a result of the refinery's normal operations, nickel particles were discharged which, over the course of many decades, accumulated in the soil of neighbouring properties. The trial judge made reference to the above-quoted passage from Linden and Feldthusen, and imposed strict liability on the basis of Inco Ltd.’s “abnormally dangerous activities.”137

That aspect of the trial judge's decision was specifically overturned on appeal. The Court stated that " $[\mathrm{w}] \mathrm{e}$ do not accept that strict liability based exclusively on the 'extra hazardous' nature of the defendant's conduct is or should be part of the common law in this province."138 The Court justified the conclusion because, while there may be strong policy reasons to impose strict liability on those that engage in ultra-hazardous activities, those decisions are best made through legislative action, applicable to specifically defined activities, rather than by judicial fiat. ${ }^{139}$

For now, the doctrine of strict liability for ultra-hazardous activities is not a part of Canadian law. That discussion is bolstered by the fact that the Supreme Court of Canada denied leave to appeal in the Inco case. ${ }^{140}$ However, it remains possible that litigants in provinces other than Ontario may ask courts in those jurisdictions to distinguish the Inco case and rely upon the doctrine of strict liability for ultra-hazardous activities in different contexts and on different facts. It would not be surprising to see oil and gas producers in western Canada faced with the argument that hydraulic fracturing operations should be classified as ultra-hazardous activities with strict liability resulting for any damages caused by those operations, regardless of the circumstances in which those damages were caused.

\section{b. Issues of Proof}

In any litigation arising from hydraulic fracturing operations, issues of proof, with specific reference to causation, will be front and centre. Some cases may pose no such difficulty. For example, a discharge of fracking fluid at the surface will not give rise to serious issues of causation, at least with respect to the existence of property damage. However, where a claim

Allen M Linden \& Bruce Feldthusen, Canadian Tort Law, 8th ed (Markham: LexisNexis Butterworths, 2006) at 540-41 [footnotes omitted].

See Smith v Inco Ltd, 2011 ONCA 628, 107 OR (3d) 321 [Inco].

Smith v Inco Ltd, 2010 ONSC 3790, 52 CELR (3d) 74 at paras 65-66.

Inco, supra note 136 at para 78.

Ibid at paras 85, 93.

Leave to appeal refused, 34561 (26 April 2012). 
involves allegations that soil or water has been contaminated by migrating hydrocarbons or subsurface fracturing fluid or waste water, proving the source of those substances may be difficult. Questions arising would include: What substances are present? When did those substances become present? Are those substances naturally occurring or were they introduced to the soil or water through the hydraulic fracturing operations? And, if they were introduced through hydraulic fracturing, whose operations were responsible? Further complicating matters, the production of tight oil and tight gas resources often involves multiple wells in relatively close proximity to one another. There may be multiple producers and a combination of multiple producing, suspended, injecting, or abandoned wells in any given area. If the issue is, for example, extensive groundwater pollution, and multiple producers have operations in the area, it may be difficult, if not impossible, to pinpoint the source of any specific substances, particularly given the natural subsurface movement of groundwater and hydrocarbons.

Public disclosure of the chemical composition of fracking fluid used may simplify these types of issues in the future, as would a greater emphasis on creating baseline environmental assessments of soil and water quality prior to the commencement of drilling operations. If both landowners and producers are aware of the environmental condition of soil and water prior to any operations being conducted, and they likewise know what substances are introduced through the drilling and completion process, all parties will be in a much better position to determine the effect, if any, of those hydraulic fracturing operations.

To that end, ongoing record keeping and monitoring by oil and gas producers may prove to be critical to future operations and the mitigation of litigation risk. Producers should take steps to ensure that they can demonstrate that each well drilled and completed has been properly designed and constructed in accordance with all applicable regulations and good oilfield practice. Ongoing monitoring should confirm the continued integrity of each well. Ideally, baseline studies would have been conducted to determine the condition of soil and water prior to the commencement of operations. Further, steps should be taken to adequately mitigate the risk of communication with any adjacent wellbores. Armed with this data, producers will be well-equipped to respond to claims that fracturing operations have caused harm.

\section{c. Recoverable Damages}

United States litigation and the Ernst lawsuit reviewed above provide a useful guide to the types of relief that oil and gas producers might expect to face in future Canadian actions arising from hydraulic fracturing operations. These include:

(1) Compensatory/remediation damages;

(2) Damages for diminution of property value/stigma claims;

(3) Damages for personal injury (environmental illness claims);

(4) Damages for the cost of future medical monitoring; 
(5) Injunctive relief; and

(6) Punitive damages. ${ }^{141}$

Dealing first with compensatory/remediation damages and stigma damages, the recoverability of these should not be controversial in most cases. Expert evidence will invariably be led that will establish the extent of property damage and the costs required to remediate the property to the appropriate standard. While there will undoubtedly be arguments about the existence and extent of any damage, the cause of the damage (for example, was there pre-existing or independent damage to the property?), and the appropriate standard of remediation, these issues will be resolved in the usual fashion by the courts based on the evidence presented.

In addition to claims for damage to property, it is possible that plaintiffs in a lawsuit arising from hydraulic fracturing operations may allege that they have suffered personal injury as a result of exposure to hydrocarbons or chemicals present in hydraulic fracturing fluids. Mandatory disclosure requirements of components of those fluids may facilitate these sorts of claims, as potential plaintiffs would have a means of identifying substances that might give rise to an illness, and thereby have a base from which to launch the claim. However, knowledge of the actual substances used would only be the first step. A plaintiff would still have to base the claim upon a recognized cause of action. Assuming that hurdle is cleared, the plaintiff would then have to establish that he or she:

(1) Was in fact exposed to the specific substance;

(2) The exposure was caused by the defendant; and

(3) That the exposure to that specific substance caused or contributed to the development of a recognized medical condition.

There is nothing particularly novel about this type of claim in the legal sense, and there have been a multitude of these types of exposure/environmental illness claims advanced in other contexts, such as benzene or asbestos exposure. However, plaintiffs advancing such claims face a difficult burden of proof. Providing evidence of exposure, pinpointing the source of that exposure, and proving the causal connection between that exposure and the plaintiff's medical condition would present significant challenges.

Where plaintiffs could prove other elements of liability required, but not a recognized medical condition, those plaintiffs may still seek to recover damages on the basis that the exposure to potentially harmful substances has left them at risk of contracting, at some future date, a medical illness. On that basis, they would urge that some form of unusual and heightened medical monitoring is required. Claims for medical monitoring damages have not received significant judicial consideration in Canada. As a result, it is instructive to consider

141 The tests for injunctive relief and punitive damages are well-established in Canadian law. Specific consideration will not be given to these types of relief in this article. 
how the issue is treated in the US before turning to what Canadian jurisprudential consideration there has been.

\section{i. Medical Monitoring in the United States}

As noted above, plaintiffs in the US who claim to have been exposed to harmful substances have sought to recover the costs of future expenses for medical monitoring - in other words, ongoing medical examinations and tests that are designed to detect future illness or disease arising from an individual's exposure to those harmful substances. ${ }^{142}$ While damages for medical monitoring have been awarded in some cases, there is no common approach to these claims in various US jurisdictions. Courts continue to struggle with issues of whether this sort of claim represents an independent cause of action or merely a remedy, and whether a present physical injury must be proven as a precondition to recovery. ${ }^{143}$

\section{ii. Medical Monitoring in Canada}

The need for future medical monitoring does not appear to be sufficient to establish an independent tortious cause of action in Canada, nor has it been explicitly recognized in Canadian jurisprudence as a separate remedy or head of damages. One of the few Canadian cases to specifically consider future costs of medical monitoring is Brooks v. Canada (A.G.). ${ }^{144}$ This case suggests a restrictive view of recoverability for these types of claims. The representative plaintiff in that proposed class action was an ex-Canadian Forces member who had been exposed to Agent Orange in the 1950s while stationed at CFB Gagetown. The prayer for relief in the action included a claim for future medical surveillance expenses. ${ }^{145}$

The Court noted that medical monitoring is a remedy or damage, and is in effect a claim for pure economic loss. ${ }^{146}$ As such, an actual physical injury would need to be established before recovery could be granted. The proposed class of plaintiffs in Brooks had no such physical injuries. Further, it was noted in Brooks that medical monitoring costs are not considered pure economic loss because they seek to recover money that might be expended in the future, not money that has, in fact, been expended. ${ }^{147}$ The claim for damages was purely speculative. For those reasons, the Court explicitly rejected this claim on the floodgate

S Jean \& Mary T Yelenick, “An Introduction to Medical Monitoring” (2 July 2003), online: International Law Office <http://www.internationallawoffice.com/Newsletters/Detail.aspx?r=7018>, citing Badillo v Am Brands, 16 P 3d 435 at 438 (Nev 2001).

143 On the latter point, states such as Colorado, New York, Pennsylvania, and West Virginia allow claims for medical monitoring in the absence of a present physical injury, while other states, such as Louisiana, Oklahoma, and Texas, require proof of a present physical injury. The issue remains unresolved in other states including Arkansas, Wyoming, and North Dakota. 2009 SKQB 509, [2010] 6 WWR 81 [Brooks].

Ibid at para 6 .

Ibid at para 110.

Ibid at para 113. 
principle, stating that it could result in "liability in an indeterminate amount for an indeterminate time to an indeterminate class.”148

The law in Canada on this issue is likely to evolve if these types of claims proliferate. Plaintiffs advancing such claims will be faced with the difficulty of establishing a contingent claim based upon pure economic loss. Traditional damages principles restricting recovery for pure economic loss, and the concern about creating potentially unlimited liability to an unlimited class, suggest that future Canadian courts will be very hesitant to award damages for future medical monitoring costs in the absence of physical injury.

\section{LitigATION RisKS VIS-À-VIS OTHER OIL AND GAS PRODUCERS}

Oil and gas producers face an entirely different set of litigation risks with respect to the impact their operations may have on other producers. There are a number of circumstances where HMSF operations may have an impact on the operations of other producers, which include:

(1) The impacts on adjacent wellbores;

(2) Reservoir damage; and

(3) Subsurface trespass/drainage issues.

Each will be considered in turn.

\section{a. Impacts on Adjacent Wellbores}

The potential for hydraulic fracturing operations to have unintended impacts on adjacent wellbores has been recently recognized by the ERCB in Bulletin 2012-02. ${ }^{149}$ Impacts can range from an increase in pressure noted at the adjacent well, to fracturing fluid being detected in production from the adjacent well, to an actual fluid-to-surface event with environmental impacts or a true well blowout. Bulletin 2012-02 states, in part:

In recent years, there has been an increase in energy companies using horizontal wells and multistage hydraulic fracturing to stimulate the flow of oil or gas in deep formations throughout Alberta. The Energy Resources Conservation Board (ERCB) is aware that communication between a wellbore being stimulated and an offset energy wellbore that penetrates the same formation can and has occurred. Offset wellbores include wells that are being drilled or stimulated or those that are producing, suspended, or abandoned.

Ibid at para 114, citing Hoffman v Monsanto Canada, 2005 SKQB 225, [2005] 7 WWR 665 at para 73. See also Bryson v Canada (AG), 2009 NBQB 204, 358 NBR (2d) 1 [Bryson], which also involved an application for certification of a class action brought on behalf of individuals allegedly exposed to harmful substances on a military base. The Crown opposed the claim for medical monitoring expenses on the basis that it would lead to unlimited liability to an unlimited class. While the Court acknowledged that this was a novel claim in Canadian law, it held that the claim should at least be allowed to undergo a full analysis at trial (Bryson, ibid at para 35). 
The ERCB fully expects licensees to maintain well control at all times so as not to impact the environment, public safety, and efficient recovery of the resource and to prevent adverse effects to offset energy wellbores. The ERCB reminds industry that it is obligated to plan safe and effective hydraulic fracturing operations and report any unintentional communication between energy wellbores. ${ }^{150}$

This Bulletin was issued, at least in part, in response to a well blowout which occurred near Innisfail, Alberta in January 2012. Preliminary indications are that the blowout was caused by communication between that vertical well and a hydraulic fracturing operation being conducted on a nearby horizontal well. ${ }^{151}$

While scientific modeling based upon the geologic characteristics of the relevant formation allows producers to accurately predict the length and direction of fractures created, there remains some residual uncertainty about exactly how far and in what direction those fractures will in fact extend. Prudent operators will be cognizant of any potential impacts on adjacent wellbores and will take steps to mitigate that risk. Co-operative efforts between producers, which may include, in rare circumstances of higher risk, the owners of adjacent wells voluntarily shutting in production while hydraulic fracturing is being carried out, should effectively mitigate the residual risk of unintended impacts in almost all instances.

In the event that such impacts do occur, producers conducting HMSF operations can expect to be faced with claims from the affected producers for the value of any lost production, third party damages related to a failure to meet contracted production volumes, and to be indemnified with respect to any claims that may be advanced by a landowner whose property may have been damaged.

\section{b. Reservoir Damage}

In rare circumstances, it is possible that hydraulic fracturing operations may have an adverse impact on the producing formation. Other producers may, therefore, be hindered or prevented from producing oil or natural gas that would otherwise have been recoverable. For example, if the fractures breached an adjacent water-bearing reservoir, the result may be that the producing formation may be flooded, rendering any remaining hydrocarbons unrecoverable. In such circumstances, the producer responsible for the hydraulic fracturing operation may be faced with claims based in negligence from affected producers seeking the value of any lost production, or recovery of costs newly incurred to produce from the formation now impacted by water.

\section{c. $\quad$ Subsurface Trespass/Drainage Issues}

A variety of circumstances exist whereby producers, through hydraulic fracturing, may find themselves faced with competing claims for the hydrocarbons produced. The length of fractures created is not capable of precise control. They may extend 200 meters or more with the result being that the reach of a horizontal well, drilled within applicable spacing unit and

See Dina O’Meara, "Regulators say hydraulic fracturing may have caused oil spill on farm near Innisfail," Calgary Herald (17 January 2012), online: Calgary Herald <http://www.calgaryherald.com/ business/Hydraulic+fracturing+have+caused+well+blowout/6003589/story.html>. 
set-back regulations, extends beyond boundaries within which the producer may arguably be entitled to produce. In short, fractures may extend from the wellbore horizontally across lease boundaries. ${ }^{152}$ Alternatively, a producer with mineral rights to a single zone may fracture from a wellbore in that zone into an adjacent zone (above or below) and access hydrocarbons for which the mineral rights belong to another party. A third possibility, as alleged in the CrossAlta action referred to above, is that a fracture may extend into a gas storage reservoir, thereby allowing access to natural gas which has been injected for storage by another party. In each such instance, the producer responsible for the hydraulic fracturing operation may be faced with a claim based upon subsurface trespass, negligence, conversion, or unjust enrichment seeking damages for the drainage which results.

With respect to the scenario involving fractures that extend horizontally across lease boundaries, there is uncertainty in Canadian law whether the rule of capture would insulate the producer from a claim for damages based upon any resulting drainage. The rule of capture, stated simply, is as follows: "The owner of a tract of land acquires title to the oil or gas which he produces from wells drilled thereon, though it may be proved that part of such oil or gas migrated from adjoining lands."153

The rule of capture has been recognized generally in Canadian law. ${ }^{154}$ However, whether the rule would apply in the specific context of fractures created across lease boundaries has not been considered. There is American jurisprudence suggesting that the rule of capture applies only where any drainage occurs naturally — the rule does not apply where some artificial means have been introduced to induce or enhance the flow of hydrocarbons. ${ }^{155}$ This particular limitation on the rule of capture has not been considered or applied by a Canadian court.

Further guidance on the specific application of the rule of capture where hydraulic fracturing operations extend across lease boundaries can be found in the Texas Supreme Court's decision in Coastal Oil \& Gas Corp. v. Garza Energy Trust. ${ }^{156}$ In Garza, the plaintiff advanced an action alleging subsurface trespass (based upon hydraulic fracturing operations on an adjacent parcel of land) and sought damages for the resulting drainage of natural gas. The Court denied the claim on the basis that an actionable trespass in that circumstance required proof of actual injury. ${ }^{157}$ As the drainage claim was barred by the rule of capture,

For a more detailed consideration of this issue, see William M Laurin, "Fracking Across Adverse Ownership Boundaries,” The Negotiator (March 2012) at 3, online: CAPL <http://www.landman.ca/ publications/Negotiator/2012/mar/march12_layout.pdf $>$.

Robert E Hardwicke, “The Rule of Capture and its Implications as Applied to Oil and Gas” (1935) 13:4 Tex L Rev 391 at 393.

See Borys v CPR, [1953] 2 DLR 65 (PC). See also Cecilia A Low, “The Rule of Capture: Its Current Status and Some Issues to Consider” (2009) 46:3 Alta L Rev 799.

See e.g. Manufacturers’ Gas \& Oil Co v Indiana Natural Gas \& Oil Co, 57 NE 912 (Ind Sup Ct 1900); Richmond Natural Gas Co v Enterprise Natural Gas Co, 66 NE 782 (Ind Ct App 1903).

268 SW 3d 1, (Tex Sup Ct 2008) [Garza].

Courts in Colorado, Ohio, and Oklahoma have similarly ruled that an action for subsurface trespass requires proof of actual damage. See e.g. Board of County Commissioners $v$ Park County Sportsmen's Ranch LLP, 45 P 3d 693 (Colo Sup Ct 2002); Chance v BP Chemicals, 670 NE 2d 985 (Ohio Sup Ct 1996); West Edmond Salt Water Disposal Association v Rosecrans, 226 P 2d 965 (Okla Sup Ct 1950). For further analysis of these cases, see Barclay Nicholson \& Brian Albrecht, "Hydraulic Fracturing: Subsurface Trespass Emerging Issue,” The American Oil \& Gas Reporter (February 2012), online: Fulbright \& Jawovski LLP <http://www.fulbright.com/images/publications/20120201AOGRSub surfaceTrespassNicholson.pdf>. 
there was no actionable trespass. ${ }^{158}$ With no injury proved, the Court did not have to decide whether the subsurface injection of hydraulic fracturing fluids and proppant constituted a trespass.

Several additional aspects of the Garza decision are noteworthy. First, the obvious corollary to the Court's ruling is that an action for subsurface trespass in the context of HMSF operations may lie if there is proof of actual injury. Such actual injury may result from communication with adjacent wellbores or reservoir damage, as discussed above.

Second, the Court was clearly influenced in its decision by public policy considerations. The majority of the Court made reference to the essential role that hydraulic fracturing plays in modern oil and gas production ${ }^{159}$ and referenced the multitude of amicus curiae briefs received from regulators, landowners, royalty owners, operators, and hydraulic fracturing service providers, almost all of which opposed liability. ${ }^{160}$ The minority concurring opinion of Justice Willett set forth the prevailing public policy view in the starkest of language:

\begin{abstract}
Bottom line: We are more and more over a barrel as "our reserves of fossil fuels are becoming harder and more expensive to find." Given this supply-side slide, maximizing recovery via fracing is essential; enshrining trespass liability for fracing (a "tres-frac” claim) is not. I join today’s no-liability result and suggest another reason for barring tres-frac suits: Open-ended liability threatens to inflict grave and unmitigable harm, ensuring that much of our State's undeveloped energy supplies would stay that way undeveloped. Texas oil and gas law favors drilling wells, not drilling consumers. Amid soaring demand and sagging supply, Texas common law must accommodate cutting-edge technologies able to extract untold reserves from unconventional fields. ${ }^{161}$
\end{abstract}

Third, there was a dissenting opinion in Garza that embraced the more limited application of the rule of capture, which says that the rule applies only where any drainage occurs naturally, without any artificial means employed to enhance the flow of hydrocarbons. ${ }^{162}$ This dissenting opinion highlights the fact that there is still room for argument with respect to the exact scope and definition of the rule of capture. These issues have not been explicitly considered by a Canadian court, but at least one commentator has suggested that the decision of the majority in Garza might not be followed:

We may accept that we have arrived in a world where the Rule of Capture affords forgiveness for subsurface drainage predominantly on the basis that we cannot prove where the drainage occurred from, however if science provides concrete mechanisms for demonstrating where the drainage is occurring, do the rules change? Recent advancements in microseismic monitoring of the fracking process has resulted in seemingly precise estimates of the size and orientation of the hydraulically induced fractures....If service company promotional material is to be believed, the extent and density of fractures and proppant incursion can be

Garza, supra note 156 at 12-13. The Court offered four bases as justification for application of the rule of capture in these circumstances: (1) the mineral owner can protect himself by drilling and fracking his own off-set well; (2) a ruling by the Court on this issue would usurp the role of the regulatory body that makes rules to balance the respective rights of mineral owners; (3) courts are ill-equipped to determine the extent of drainage caused by fracking; and (4) no one in the industry appears to want or need a change to the law of trespass (ibid at 14-17). Ibid at 7.

Ibid at 16-17.

Ibid at 29 [footnote omitted].

Ibid at 42. 
mapped with alarming accuracy. As many of the advances in fracture monitoring have occurred in the past three years (i.e. since the decision in Garza), we are left to speculate about the impact that kind of visually compelling evidence would have on a court in Canada, or elsewhere. ${ }^{163}$

Thus, the issue of whether an oil and gas producer who fractures across subsurface lease boundaries will be liable to the mineral rights owner of that adjacent parcel of land for any resulting drainage remains unresolved in Canada. The most that can be said is that producers who do fracture across subsurface lease boundaries may face liability for drainage-based damage claims.

The foregoing consideration of the rule of capture and fracturing across lease boundaries assumes that the parties advancing competing claims to the hydrocarbons produced both have rights to produce from the same common pool or zone, which happens to be accessible from adjacent parcels of land. The situation is very different where the fractures created extend vertically into a zone in which the mineral rights belong to another party. The rule of capture has never been used to insulate a producer from liability in that circumstance and such would be fundamentally contrary to the established mineral ownership regime. Were the circumstances to arise, the producer who caused the communication between zones by hydraulic fracturing would face the very real risk of a valid claim for damages by the owner of the mineral rights in that other zone.

Likewise, it seems unlikely that, in Canada, a producer who, through hydraulic fracturing, causes communication between a producing wellbore and a properly defined gas storage reservoir, would be entitled to rely upon the rule of capture to avoid liability to the owner of the storage gas. While the issue has not been directly considered by a Canadian court,

the consensus U.S. position seems to be that where the person injecting the gas did not intend to abandon it, and has injected it into an adequately defined cavern, the ownership of the gas remains with that person. Abandonment is only to be inferred where oil or gas has been injected into "a formation that is not well defined, [thus] the owner has physically relinquished the property by putting it beyond control ... [Abandonment will not be inferred where] the injector reasonably believes that the storage reservoir is well defined. $^{164}$

At the very least, producers who, through hydraulic fracturing cause communication between their wellbore and a gas storage reservoir, would face a risk of liability for damages to the owners of the storage gas.

\section{Fracturing Litigation SUMMARY}

It is apparent that Canadian oil and gas producers must be cognizant of the potential for litigation as a risk arising from the conduct of hydraulic fracturing operations. Potential plaintiffs, including both private landowners and other oil and gas producers, may have various causes of action and types of relief available to them in different factual contexts. 
Regardless of the plaintiff and the context, it is safe to comment that the most effective means for producers to mitigate the risks of litigation arising from hydraulic fracturing lies in establishing sound operational practices, adhering to all regulatory requirements, and undertaking effective monitoring and record-keeping.

Hydraulic fracturing has, for decades, been safely conducted in the completion of thousands of wells in western Canada. This suggests that there is no systemic or inherent risk associated with the practice of hydraulic fracturing. With appropriate operational safeguards in place, including compliance with all applicable regulatory requirements, oil and gas producers should be confident in their ability to continue to use HMSF technology to unlock previously unrecoverable reserves of oil and gas without courting excessive litigation-related risks.

\section{CONCLUSION}

The proliferation of HMSF in North America has spurred numerous lawsuits and a process of regulatory re-evaluation in many jurisdictions. The legal and regulatory environments are quickly adjusting to the issues raised by the widespread use of HMSF. Traditional tort law principles are being adapted, and goals of transparency and mandating best practices are guiding regulatory developments. Further evolution in these respects can be expected as the HMSF process itself becomes better understood by courts, government, and the public.

We hope that this article has helped the reader gain a better understanding of the developing legal and regulatory environment for hydraulic fracturing and will assist in considering the myriad of legal and regulatory issues that may arise in the future. 